\title{
Violence against children and adolescents: a public health issue?
}

\section{Introduction}

This essay displays part of the research "The impact of intrafamily violence in childhood and youth: a public health issue" developed in a doctoral dissertation (USA) doctoral thesis (UK.). The overall objective of this study was to investigate intrafamily violence in children and adolescents treated at the John XXIII State Public First Aid Hospital, in Minas Gerais state.

A question to deal with along the dissertation was to find out whether the cases that arrive at the Hospital reported as accidents hide the violence, leading to initial hypothesis in which domestic accidents, actually, hide what has not been said, or rather, hide the intrafamily violence.

This research also had the specific objectives of describing the profile of families, children and adolescents who received medical care; typifying the acts of violence those children and adolescents went through; as well as identifying factors associated with the occurrence of violence in this scenario.

In this context, we performed a quantitative survey using patient charts to collect information that display the profile of the child or adolescent and their family, generating social indicators. The research also aimed at obtaining supporting information to understand and go deeper into the questions that permeate intrafamily violence and its impact on the life of the victim and relatives. The theoretical framework used was the Institutional Analysis of René Lourau. The Institutional Analysis aims to produce a new relationship with the knowledge, a consciousness of the non-knowledge that determines the researcher's action, who is in the field of research implied as an observer, and his /her intervention may bring transformations for both the research and the environment where it takes action.

Patients' medical charts were used to analyze quantitatively the profile of children, adolescents and families. A total of 1,152 medical records from the Medical and Statistical Archive Service issued in the first half of 2012 were analyzed. Belo Horizonte is the city that mostly demands services from the Hospital.

\section{The highest rates of occurrences were}

Falls (20.5\%), accidents (14.3\%), burns (12.2\%), aggression $(10.2 \%)$ and foreign body (7.6\%). Males represents $70.9 \%$ of the cases. Remarkably, the mother is the main aggressor. It was found that many of the cases that come to the hospital described as an accident do, in fact, indicate characteristics of violence, although not always reported. This study allowed us to conclude that intrafamily violence is a public health issue that deserves attention from society and public power. It can be seen that a large percentage of young children go through hospital care, $36.7 \%$ of whom are between 0 and 6 years old. Often, they are not identified as victims of violence, but are treated in a variety of situations. We remark that young children are often scarcely able to report what happened to them, and it is very difficult to identify the cases of violence. The data we have found comply with those reported throughout the nation. The Violence and Accident Surveillance System (VIVA) held by the Ministry of Health,
Volume 4 Issue 2 - 2019

\author{
Fernanda Flaviana de Souza Martins \\ Social Worker, PhD in Psychology at PUCMinas, Pontifical \\ Catholic University of Minas Gerais, Brazil
}

\author{
Correspondence: Fernanda Flaviana de Souza Martins, Social \\ Worker, PhD in Psychology at PUCMinas, Pontifical Catholic \\ University of Minas Gerais, Brazil, \\ Email fernandasocial@gmail.com
}

Received: April 23, 2018 | Published: March 0I, 2019

referring to studies carried out in the years 2006-2007, points out that: “(...) children, because they are more dependent and less capable of self-defense, are the most vulnerable to violence perpetrated by adults "(Moreira, Sousa \& Alves, 2013, page 48), which allows us to attest the difficulty to unveil this type of violence within the family environment

\section{The hospitalization and its causes}

Regarding the reasons for hospital care, the highest occurrences are among accidents, falls, burns and aggressions. According to the Ministry of Health, accidents and violence in Brazil comprises a public health problem of great magnitude and transcendence, with a strong impact on the morbidity and mortality of the population. ${ }^{1}$ In addition, the same institution points out that accidents and violence come out either from human actions or omissions as well as from technical and social factors. Concerning accidents, it says that "[...] they are understood as unintentional and avoidable events, causing physical and / or emotional injuries. It is assumed that such events are, to a greater or lesser degree, perfectly predictable and preventable "(Brazil, 2000, p.427). The theme is included in the expanded concept of health that encompasses not only medical and biomedical issues, but also those related to lifestyles and to the set of social, historical and environmental conditions. "When analyzing the matter of accidents and violence from the perspective of population segments, there are remarkable peculiarities, concerning both the occurrences as well as their characteristics and circumstances" (Brazil, 2000, p.427). It is noticeable that the greatest difficulty has been the denial of the violence phenomenon. Our country, according to Oliveira and Flores, ${ }^{2}$ already in the 1990s, presented serious deficiencies concerning epidemiological data as much as the lack of public policies dealing with intrafamily violence against children and adolescents. Despite the date of this study, the current conditions are not quite different. There is a lack of reliable national statistical data about violence against children and adolescents in Brazil, which makes it difficult to face the phenomenon. The availability is restricted to records of isolated services or from researchers' records. Weber et al. ${ }^{3}$ estimates that only $20 \%$ of cases of violence are reported. "The report of cases to competent institutions is a practice scarcely exercised by the community and a silence pact hangs over the matter, bringing harm to the child and the family". ${ }^{3}$

Danosso \& Ricas ${ }^{4}$ recall the advances concerning the matter of child abuse, especially in the realm of sciences, and professionals' recognition of physical punishment as being violence. For the authors, 
the tendency to disapprove physical punishment, shifting it, regardless its form and intensity, to the category of violence is based on studies and observations that show the risks and consequences of this practice towards the children. On the other hand, such punishments may not be perceived as violence by those who practice them, due to their diffusion and social acceptance. Martins ${ }^{5}$ points out that the culturally accepted limits of intensity, frequency and forms of educational physical punishment vary widely between social groups and families. Danosso \& Ricas ${ }^{4}$ warn that a slap or beating can be justified as an educational necessity. This educational need considered by parents can often cover up other situations and intentions which may be conscious or not, motivated by feelings such as hatred, frustration, anger and others, as authors say: "[...] from the adult against the children or driven towards them "(2009, 79). In the context of this research, although not named as intrafamily violence, children and adolescents arrive at the hospital due to several reasons and situations.

\section{Final considerations}

When examining the quantitative data of the research, it is noticeable that although it initially tried to understand just the intrafamily violence, it is also visible that it comes out and is approached in the hospital scope, including how it is manifested in the children and adolescents' daily life in several different shapes. In addition, violence is present in the context of health professionals' interventions who deal with their effects on daily work. It is believed that the results presented can support the implementation of public policies aimed at coping with domestic violence. For example, the data presented show a high incidence of occurrences in young children, which suggests preventive actions and the strengthening of the family nucleus. The study also discloses that nearly $50 \%$ of the cases brought to the hospital and reported as accidents actually hid a situation of intrafamily violence against children and adolescents the study allowed to conclude that intrafamily violence presents itself as a public health issue that deserves attention from society and public power.

\section{Acknowledgments}

None.

\section{Conflicts of interest}

Authors declare that there are no conflicts of interest.

\section{References}

1. Ministério da Saúde. Secretaria de Assistência à Saúde. Notificação de maus-tratos contra crianças e adolescentes pelos profissionais de saúde: um passo a mais na cidadania em saúde. [ Health professionals' report of mistreatments against children and adolescents: one step more towards citizenship concerning health] Brasília: Ministério da Saúde, 2002.

2. Oliveira MS, Flores RZ. Violência contra crianças e adolescentes na Grande Porto Alegre - Parte A: apenas boas intenções não bastam. [Violence against children and adolescents in metropolitan Porto Alegre - Part A: Just good intentions are not enough.] In: Associação de apoio à criança e ao adolescente - Amencar (Org.) porto alegre: amencar. 1999.

3. Weber LN. Famílias que maltratam: uma tentativa de socialização pela violência.[ Families that mistreat: an attempt towards socialization through violence.] Psico- USF. 2002;7(2):163-173.

4. Donoso, MTV. Ricas J. Perspectiva dos pais sobre educação e castigo físico.[Parents'perspective on education and physical punishment]. Revista de Saúde Pública. 2009;43(1):78-84.

5. Martins FFS. Crianças negligenciadas: a face (in) visível da violência familiar. [Neglected children, an/a (in) visible face of family violence] 127f. Dissertação (mestrado em Psicologia)-[Master degree dissertation in Psychology] Belo Horizonte, Pontifícia Universidade católica de minas gerais. 2006. 